\title{
Low-dose extrapolation in toxicology: an old controversy revisited
}

\author{
Hermann M. Bolt · Rosemarie Marchan • \\ Jan G. Hengstler
}

Published online: 27 February 2009

(C) Springer-Verlag 2009

A conservative strategy of estimating toxicity at low doses is to determine the risk at high doses and connect the highlevel risk to the zero intercept (Hengstler et al. 2003). However, in some cases this type of extrapolation may result in unreasonable conclusions. To illustrate the inappropriateness of the linear dose-response extrapolation, a ban of high-heeled shoes has been used as a humorous analogy for the following reason (Goldman 1996): Assume that every human being on earth adds a $3-\mathrm{cm}$ lift to his shoes. It is well known that cosmic ray dose doubles for every $2,000 \mathrm{~m}$ in altitude, but the resulting increase in cosmic ray dose by high-heeled shoes is extremely small. However, multiplied by the population of earth, this would result in a dose that causes cancer in approximately 30,000 individuals in 50 years (from Hengstler et al. 2003). Mathematically this example is accurate, but thus far no one has seriously considered banning high-heeled shoes.

In recent years strong evidence has been presented that toxicology should differentiate between two types of genotoxic carcinogens, those acting by a practical threshold and those acting by a non-threshold mechanism or by a mechanism for which a threshold has not yet been defined (Bolt and Huici-Montagud 2008). On the other hand, it is dangerous to generalize that safe levels of exposure exist. In this context, the example of aflatoxin $\mathrm{B}_{1}$ is often mentioned because there is still no convincing evidence suggesting that safe doses of aflatoxin $B_{1}$ exist.

Of course, it is well established that a single molecule of a genotoxic carcinogen is not sufficient to transform a

H. M. Bolt · R. Marchan · J. G. Hengstler $(\square)$ Leibniz-Institut für Arbeitsforschung an der TU Dortmund, Leibniz Research Centre for Working Environment and Human Factors (IfADo), Ardeystrasse 67, 44139 Dortmund, Germany e-mail: hengstler@ifado.de healthy cell into a cancer cell, because more than one mutation is needed. For instance, at least two oncogenes must be activated and one tumor suppressor inactivated to facilitate the transformation of normal mouse ovarian surface epithelial cells to ovarian carcinomas (Orsulic et al. 2002). However, as long as thresholds have not been clearly demonstrated, which still is the case for the majority of genotoxic carcinogens, a linear low dose-response extrapolation seems to be conservative but adequate for regulatory purposes.

Extrapolation to in vivo relevant concentrations (Sogorb et al. 2007; Glahn et al. 2008; Schug et al. 2008; Borza et al. 2008), dose-response relationships (Dorn et al. 2008; O'Brien et al. 2006; Pelkonen et al. 2008, Levy et al. 2007), and toxicity testing strategies (Lilienblum et al. 2008; Greim 2007; Blaauboer and Andersen 2007; Naraharisetti et al. 2008; Kanno et al. 2008; Hewitt et al. 2007; Chan et al. 2008) are among the cutting-edge topics reported in our journal. Therefore, the authors are happy that Edward J. Calabrese from the University of Massachusetts has contributed two review articles to this edition of the Archives of Toxicology:

- The road to linearity: why linearity at low doses became the basis for carcinogen risk assessment;

- Getting the dose response wrong: why hormesis became marginalized by the threshold model.

In his first contribution, Ed Calabrese reviews the scientific and historical foundations of how linearity at low doses became the basis for carcinogenic risk assessment. In his second review, he addresses one of the most controversial topics in toxicology, namely the hormetic response, a $\mathrm{J}$-shaped dose response which results from the ability of some compounds to stimulate certain mechanisms at low doses and inhibit the same mechanisms at higher concentrations. 


\section{References}

Blaauboer BJ, Andersen ME (2007) The need for a new toxicity testing and risk analysis paradigm to implement REACH or any other large scale testing initiative. Arch Toxicol 81:385-387

Bolt HM, Huici-Montagud A (2008) Strategy of the scientific committee on occupational exposure limits (SCOEL) in the derivation of occupational exposure limits for carcinogens and mutagens. Arch Toxicol 82:61-64

Borza A, Plöttner S, Wolf A, Behm C, Selinski S, Hengstler JG, Roos PH, Bolt HM, Kuhlmann J, Föllmann W (2008) Synergism of aromatic amines and benzo[a]pyrene in induction of Ah receptordependent genes. Arch Toxicol 82:973-980

Chan PC, Sills RC, Kissling GE, Nyska A, Richter W (2008) Induction of thyroid and liver tumors by chronic exposure to 2-methylimidazole in F344/N rats and B6C3F1 mice. Arch Toxicol 82:399-412

Dorn SB, Bolt HM, Thevis M, Diel P, Degen GH (2008) Induction of micronuclei in V79 cells by the anabolic doping steroids tetrahydrogestrinone and trenbolone. Arch Toxicol 82:257-263

Glahn F, Schmidt-Heck W, Zellmer S, Guthke R, Wiese J, Golka K, Hergenröder R, Degen GH, Lehmann T, Hermes M, Schormann W, Brulport M, Bauer A, Bedawy E, Gebhardt R, Hengstler JG, Foth H (2008) Cadmium, cobalt and lead cause stress response, cell cycle deregulation and increased steroid as well as xenobiotic metabolism in primary normal human bronchial epithelial cells which is coordinated by at least nine transcription factors. Arch Toxicol 82:513-524

Goldman M (1996) Cancer risk of low-level exposure. Science 271:1821-1822

Greim H (2007) Toxicological comments to the discussion about REACH (H. Greim, M. Arand, H. Autrup, H.M. Bolt, J. Bridges, E. Dybing, R. Glomot, V. Foa, R. Schulte-Hermann, Arch Toxicol 2006 80:121-124). Reply to the letter to the editor: the need for a new toxicity testing and risk analysis paradigm to implement REACH or any other large scale testing initiative, by BJ Blaauboer and ME Andersen (Arch Toxicol 2007, 81:385-387). Arch Toxicol 81:895-896

Hengstler JG, Bogdanffy MS, Bolt HM, Oesch F (2003) Challenging dogma: thresholds for genotoxic carcinogens? The case of vinyl acetate. Arch Toxicol 43:485-520

Hewitt NJ, Lechón MJ, Houston JB, Hallifax D, Brown HS, Maurel P, Kenna JG, Gustavsson L, Lohmann C, Skonberg C, Guillouzo A, Tuschl G, Li AP, LeCluyse E, Groothuis GM, Hengstler JG
(2007) Primary hepatocytes: current understanding of the regulation of metabolic enzymes and transporter proteins, and pharmaceutical practice for the use of hepatocytes in metabolism, enzyme induction, transporter, clearance, and hepatotoxicity studies. Drug Metab Rev 39:159-234

Kanno S, Furuyama A, Hirano S (2008) Effects of eicosane, a component of nanoparticles in diesel exhaust, on surface activity of pulmonary surfactant monolayers. Arch Toxicol 82:841-850

Levy A, Cohen G, Gilat E, Kapon J, Dachir S, Abraham S, Herskovitz M, Teitelbaum Z, Raveh L (2007) Extrapolating from animal studies to the efficacy in humans of a pretreatment combination against organophosphate poisoning. Arch Toxicol 81:353-359

Lilienblum W, Dekant W, Foth H, Gebel T, Hengstler JG, Kahl R, Kramer PJ, Schweinfurth H, Wollin KM (2008) Alternative methods to safety studies in experimental animals: role in the risk assessment of chemicals under the new European Chemicals Legislation (REACH). Arch Toxicol 82:211-236

Naraharisetti SB, Aggarwal M, Sarkar SN, Malik JK (2008) Concurrent subacute exposure to arsenic through drinking water and malathion via diet in male rats: eVects on hepatic drug-metabolizing enzymes. Arch Toxicol 82:543-545

O'Brien PJ, Irwin W, Diaz D, Howard-Cofield E, Krejsa CM, Slaughter MR, Gao B, Kaludercic N, Angeline A, Bernardi P, Brain P, Hougham C (2006) High concordance of drug-induced human hepatotoxicity with in vitro cytotoxicity measured in a novel cellbased model using high content screening. Arch Toxicol 80:580604

Orsulic S, Li Y, Soslow RA, Vitale-Cross LA, Gutkind JS, Varmus HE (2002) Induction of ovarian cancer by defined multiple genetic changes in a mouse model system. Cancer Cell 1:53-62

Pelkonen O, Turpeinen M, Hakkola J, Honkakoski P, Hukkanen J, Raunio H (2008) Inhibition and induction of human cytochrome P450 enzymes: current status. Arch Toxicol 82:667-715

Schug M, Heise T, Bauer A, Storm D, Blaszkewicz M, Bedawy E, Brulport M, Geppert B, Hermes M, Föllmann W, Rapp K, Maccoux L, Schormann W, Appel KE, Oberemm A, Gundert-Remy U, Hengstler JG (2008) Primary rat hepatocytes as in vitro system for gene expression studies: comparison of sandwich, Matrigel and 2D cultures. Arch Toxicol 82:923-931

Sogorb MA, Álvarez-Escalante C, Carrera V, Vilanova E (2007) An in vitro approach for demonstrating the critical role of serum albumin in the detoxication of the carbamate carbaryl at in vivo toxicologically relevant concentrations. Arch Toxicol 81:113-119 